\title{
Influence of Some Environmental Variables on the Zooplankton Community of Aguieira Reservoir (Iberian Peninsula, Portugal): Spatial and Temporal Trends
}

\author{
Ana Maria Geraldes $^{1^{\star}}$, Rajeev Pasupuleti ${ }^{2}$ and Pedro Silva-Santos ${ }^{3}$ \\ ${ }^{1}$ CIMO, Escola Superior Agrária, Instituto Politécnico de Bragança, Campus de Santa Apolónia, \\ 5300-253 Bragança, Portugal. \\ ${ }^{2}$ Department of Biotechnology, Escola Superior Agrária, Instituto Politécnico de Bragança, \\ Campus de Santa Apolónia, 5300-253 Bragança, Portugal. \\ ${ }^{3}$ NOCTULA - Consultores em Ambiente, Quinta da Alagoa Lote 222, 1ํ Frente, 3500-606 Viseu,
}

Portugal.

\section{Authors' contributions}

This work was carried out in collaboration between all authors. Authors AMG and PSS designed the study, performed the statistical analysis, wrote the protocol and wrote the manuscript. Author RP managed the literature searches and reviewed the manuscript. All authors read and approved the final

manuscript.

Article Information

DOI: $10.9734 / A J E E / 2016 / 30661$

Editor(s):

(1) George Tsiamis, Assistant Professor of Environmental Microbiology, Department of Environmental and Natural Resources Management, University of Patras, Agrinio, Greece. Reviewers:

(1) Jarl Eivind Lovik, Norwegian Institute for Water Research (NIVA), Norway. (2) Yuri B. Okolodkov, Instituto de Ciencias Marinas y Pesquerías, Universidad Veracruzana, Boca del Río, Veracruz, México. (3) Mariana Lessa Carneiro da Silva, Centro Universitário de Brasília-UDF, Brazil. (4) Dimowo Benjamin, Federal University of Agriculture, Abeokuta, Ogun State, Nigeria. Complete Peer review History: http://www.sciencedomain.org/review-history/17547

Original Research Article

Received $24^{\text {th }}$ November 2016 Accepted $10^{\text {th }}$ January 2017 Published $18^{\text {th }}$ January 2017

\begin{abstract}
This research was aimed to assess the spatial and temporal trends in the zooplankton community of Aguieira reservoir at the Mondego catchment (Iberian Peninsula, Portugal) in response to some environmental variables. A total of 24 zooplankton as well as water samples were collected in the months of March (spring), May (early summer), September (late summer) and December (winter) of 2010 and 2011. The data from these samples was obtained by the Descriptive (range, percentage) and multivariate statistics (Non-metric Dimensional Scaling (n-MDS), Bray-Curtis distance,
\end{abstract}


Canonical Correspondence Analysis (CCA). Altogether twenty-three zooplankton species were recorded which included Rotifera (12), Cladocera (8) and Copepoda (3). In terms of abundance, Rotifera (Keratella spp. and Polyarthra sp.) dominated in May and September, while Copepoda (Copidodiaptomus numidicus and Tropocyclops prasinus) overtook in December and March. Cladocera was the least abundant taxon of which Daphnia longispina and Bosmina coregoni has shown abundance from December-March whereas Chydorus sphaericus, Ceriodaphnia pulchella and Diaphanosoma brachyurum from May-September. Results of n-MDS exhibited similar spatial and inter-annual patterns with environmental variables and zooplankton community. However, there were differences between the samples collected in the months of March/December and May/September in both the years. Results of CCA revealed water temperature and algal biomass as the main environmental gradients that influenced the zooplankton community. Since some of the observed changes in the zooplankton composition might be influenced by other complex abiotic/biotic interactions. Therefore this study suggests further research to understand the complexity of the interactions between biological, environmental and climatic parameters of the reservoir. Neverthless, understanding the dynamics and nature of zooplankton communities is crucial for the implementation of good management practices for reservoirs.

Keywords: Zooplankton; Cladocera; Copepoda; Rotifera; reservoir; Iberian Peninsula; Portugal.

\section{INTRODUCTION}

Zooplankton community is the result of colonisation followed by the species selection processes. Both, colonisation and selection depend on physical and chemical conditions of water in the reservoirs. Water quality is directly influenced by watershed geology, climate and by the degree of human disturbance [1]. Therefore, understanding the dynamics and nature of zooplankton communities may render an important source of information to implement correct management practices. This will in turn maintain water quality of the reservoirs in a perspective of multiple-use approach of these ecosystems. Zooplankton, despite of not being recognised as a biological quality element by the European Union Water Framework Directive, they show quick responses to environmental changes and so regarded as a valuable indicator to evaluate ecosystem integrity. This fact is evident from the zooplankton position in the food web. They form a crucial link in the energy transfer to higher trophic levels being a keystone in ecosystem functioning. Moreover, its size, structure, reproduction and survival, among other characteristics, are affected not only by the environmental variables (e.g., water temperature), but also by both top-down (fish or invertebrates) and bottom-up (nutrient level and phytoplankton) controls. Thus, the zooplankton community structure reflects the variability of environmental factors, disturbance events and ecosystem resilience [2-8].

The present paper is focused on the zooplankton community patterns in the Aguieira reservoir, an impoundment built on the River Mondego catchment. The aim of this research was: (1) to characterize zooplankton community and (2) to assess how zooplankton community responds to the variations of several environmental parameters.

\section{MATERIALS AND METHODS}

\subsection{Study Site}

Aguieira Reservoir (40'19'53, 83"N; 8 11'47, 76 "W) with an altitude of $441 \mathrm{~m}$ is located in the Iberian Peninsula, on the Mondego River catchment in Portugal (Fig. 1). In the reservoir region, the climate is influenced by the Mediterranean with warm, dry summers and mild winters. The area of the reservoir is 2000 ha and its total capacity is $423030 \times 103 \mathrm{m3}$. Maximum depth is about $50 \mathrm{~m}$. This reservoir was filled for the first time in 1981, and it is used mainly to generate hydro electrical power and to provide urban water supply. The catchment is occupied with intensive forestry, agriculture, livestock production and by several medium sized towns. The main industrial activities are olive oil and textiles. Further information concerning this reservoir can be found in Anonymous [9].

\subsection{Field Sampling and Laboratory Analysis}

A total of 24 zooplankton as well as water samples were collected in the months of March (spring), May (early summer), September (late summer) and December (winter) in the years 2010 and 2011 at three sampling sites: P1, P2 and P3 (Fig. 1). 

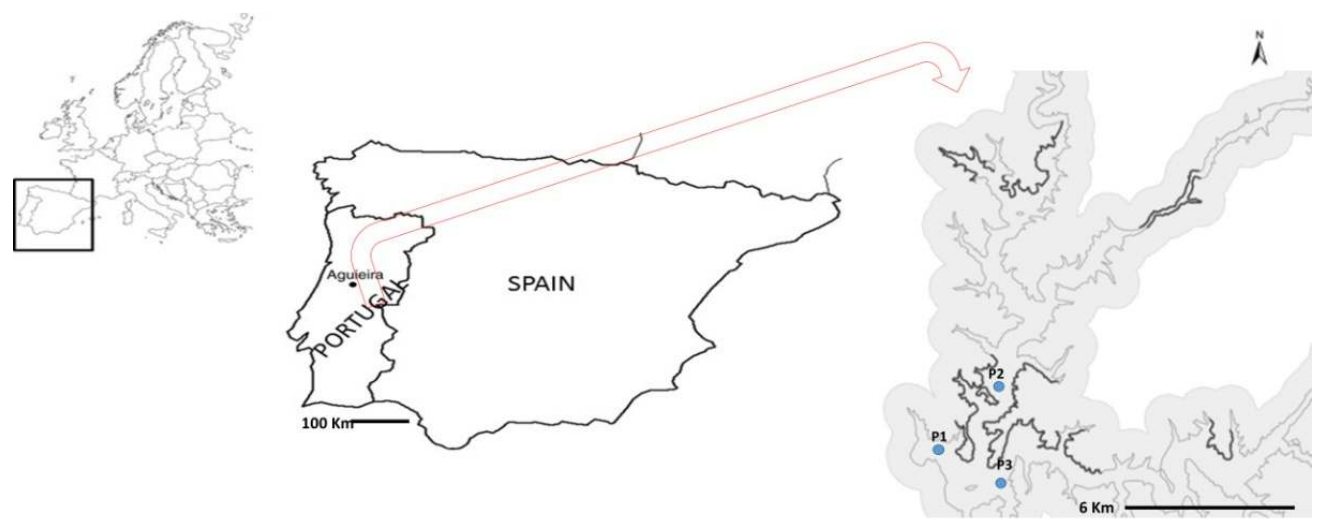

Fig. 1. Aguieira Reservoir location and sampling sites

Reservoir's map was adapted from [9]

Chlorophyll a concentrations ( $\mathrm{CHL}$ a) were calculated from water samples taken with a van Dorn bottle at $2 \mathrm{~m}$ intervals in the euphotic zone (the extension of euphotic zone was considered to be about twice the Secchi depth). Chlorophyll a concentrations were determined spectrophotometrically after overnight extraction in $90 \%$ acetone [10]. Water temperature, $\mathrm{pH}$ and conductivity were determined "in situ" using a multiparameter probe (YSI 6820). Water transparency was estimated as Secchi disk depth $(20 \mathrm{~cm}$ diameter black and white disk). Zooplankton was collected on each sampling date and site by taking two vertical hauls using a $64 \mu \mathrm{m}$ mesh size Wisconsin type net equipped with a flow meter. Hundred litres of water were filtered per each haul. Samples were concentrated to a volume of $100 \mathrm{ml}$. Animals were anaesthetized with carbonated water and preserved in sugar-saturated formaldehyde (4\% final concentration). Depending on the density, zooplankton in $5,10,20 \mathrm{ml}$ sub-samples or in total sample, were counted and identified to the genera/species level. Carlson's Trophic State Index (TSI) [11] was computed from Secchi disk transparency (TSI (SD)), and from $\mathrm{CHL}$ a concentrations (TSI (CHL)).

\subsection{Data Analyses}

Non-metric Multidimensional Scaling (n-MDS) was used to determine whether environmental variables and zooplankton community had changed seasonally, yearly and spatially. BrayCurtis distance was used to measure the dissimilarity between samples. In this method, samples were arranged in a continuum that those close together are similar and those which are far apart are dissimilar. Statistical differences between clusters identified in n-MDS plot were investigated by a randomization method, ANOSIM [12]. This method employs $R$ statistics to examine the existence of differences between the established groups for each considered factor (groups and differences between sampling sites, seasons and years). To determine the influence of the studied environmental variables on zooplankton composition, a Canonical Correspondence Analysis (CCA) was performed. In both analyses, taxa were included only if they reached a relative abundance larger than $1 \%$. Absolute zooplankton counts were transformed to $\log (x+1)$, and rare species were down weighted. In CCA the automatic forward selection procedure by Monte Carlo permutation tests (9999 permutations) was used to remove the redundant environmental variables, allowing the selection of those contributing to the explanation of the whole data set [13].

\section{RESULTS}

\subsection{Environmental Variables}

Environmental variables showed similar values during both years in each sampling site (Table 1). Spatial and inter-annual variations in these parameters were not relevant. However, n-MDS ordination (Fig. 2) was able to differentiate two groups: Samples obtained in December and March (winter and spring) from those obtained in May and September (early and late summer) (2D stress: 0.02). ANOSIM test confirmed significant differences between the two groups $(R=0.829 ; p<0.001)$. The highest values for water temperature, $\mathrm{pH}, \mathrm{CHL}$ a concentrations were observed in the samples obtained in May and September. Conversely, the highest values of Secchi disk depth were observed in December and March. According to Carlson's Trophic State 
Index (the two components together- TSI (SD) and TSI (CHL a), this reservoir was classified as mesotrophic in December and March (the values ranged between 24 and 42 for both components of the index). In May and September, it was eutrophic (values of both components of the index (SD and $\mathrm{CHL}$ a reached 57 ).

\subsection{Zooplankton Community}

During the sampling period 12 taxa of Rotifera, 8 of Cladocera and 3 of Copepoda were recorded (Table 2). The zooplankton community was dominated in May and September by Rotifera (mainly Keratella and Polyarthra), whereas Copepoda (mainly Copidodiaptomus numidicus and Tropocyclops prasinus) were dominant in December and March. Cladocera was the less abundant taxon. It was represented in December and March, mainly by Daphnia longispina and Bosmina coregoni. Conversely, in May and September by Chydorus sphaericus, Ceriodaphnia pulchella and Diaphanosoma brachyurum (Figs. 3, 4 and 5). n-MDS ordination (Fig. 6) was able to differentiate the occurring shifts between the samples obtained in December and March and those obtained in May and September (2D stress: 0.12). ANOSIM test confirmed the significant differences between the two groups $(R=0.803 ; p<0.001)$.

The diagram depicted on Fig. 7 resulted from CCA analysis applied to the most correlated environmental variables and zooplankton taxa. The ordination space defined by the first two CCA axis accounted for $70 \%$ of speciesenvironment relation and represented $45 \%$ of the variation in species data. With forward selection and Monte Carlo permutation test, a sub-set of environmental variables that significantly $(p<0.05)$ explained the variation in species data was identified. In descending order of significance, the variables included in that subset were: water temperature $(P=0.0000), C H L$ a $(P=0.004)$, Secchi disk depth $(P=0.004)$ and conductivity $(P=0.009)$. Therefore, some species/genera were found to be associated to the increase of water temperature and of algal biomass ( $\mathrm{CHL}$ a concentrations). These were all the Rotifera (excepting Gastropus sp.) and the Cladocera Ceriodaphnia pulchella, Diaphanosma brachyurum and Chydorus sphaericus. Whereas, Copepoda and the Cladocera (Daphnia longispina, Bosmina coregoni and B. longirostris) were related to lower water temperature, algal biomass and to the increase in water transparency (higher Secchi disc depth).

Table 1. Minimum-maximum range of environmental variables obtained for 2010 and 2011 from the different sampling sites

\begin{tabular}{lllllll}
\hline Parameter & \multicolumn{3}{c}{$\mathbf{2 0 1 0}$} & \multicolumn{2}{c}{ 2011 } \\
\cline { 2 - 6 } & P1 & P2 & P3 & P1 & P2 & P3 \\
\hline Water temperature $\left({ }^{\circ} \mathrm{C}\right)$ & $11.9-23.0$ & $12.2-23.2$ & $12.8-22.8$ & $14.7-25.0$ & $14.2-26.0$ & $13.4-25.3$ \\
$\mathrm{pH}$ & $7.3-9.9$ & $7.2-10.1$ & $7.3-10.0$ & $7.1-9.8$ & $7.2-10.2$ & $7.3-9.7$ \\
Conductivity $\left(\mu \mathrm{S} \mathrm{cm}^{-1}\right)$ & $70.4-104.5$ & $76.2-100.1$ & $68.8-94.6$ & $64.8-104.5$ & $63.4-102.1$ & $62.0-102.6$ \\
Secchi disk $(\mathrm{m})$ & $1.5-3.0$ & $1.5-3.0$ & $1.5-3.0$ & $1.2-4.0$ & $1.2-5.0$ & $1.2-5.5$ \\
Chlorophyll $\mathrm{a}\left(\mathrm{\mu g} \mathrm{L}^{-1}\right)$ & $0.4-16.2$ & $0.4-14.2$ & $1.4-15.7$ & $0.5-14.4$ & $0.9-10.7$ & $0.5-5.9$ \\
\hline
\end{tabular}

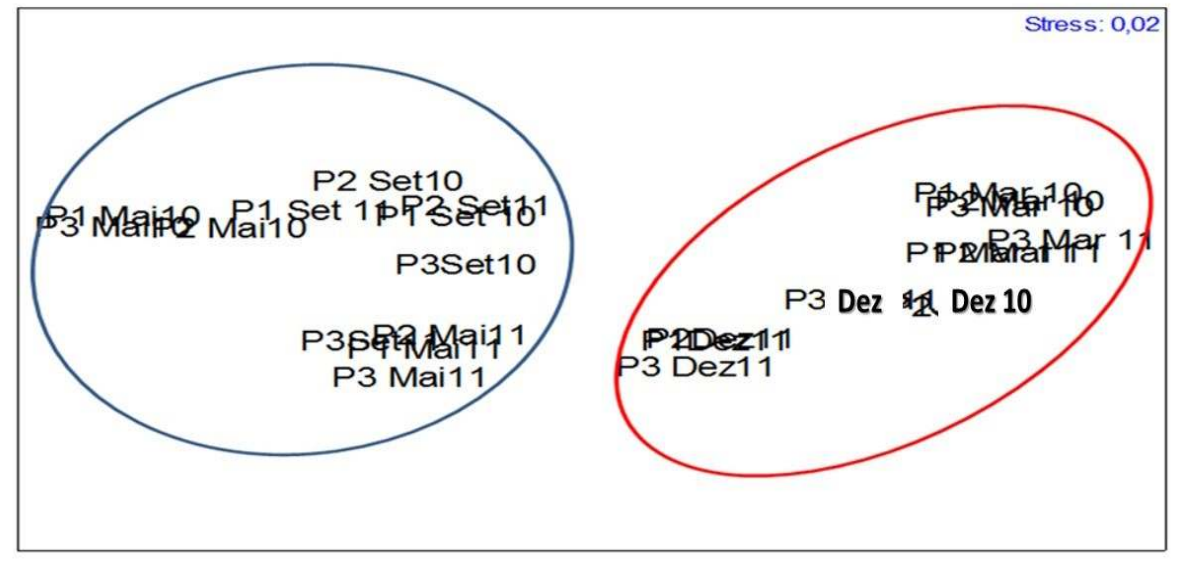

Fig. 2. Results of $n-M D S$ ordination considering environmental variables Sampling sites: $P 1, P 2, P 3$

Dez, Mar, Mai, Set: Samples obtained in December, March, May and September, respectively 
Table 2. Taxonomic composition of zooplankton community between 2010 and 2011

\begin{tabular}{lll}
\hline Rotifera & Cladocera & Copedoda \\
\hline Asplanchna priodonta & Alona sp. & Acanthocyclops robustus \\
Brachionus sp. & Bosmina coregoni & Copidodiaptomus numidicus \\
Conochilus sp. & Bosmina longirostris & Tropocyclops prasinus \\
Filinia sp. & Ceriodaphnia pulchella & Nauplii \\
Gastropus sp. & Chydorus sphaericus & \\
Hexarthra mira & Daphnia longispina & \\
Keratella cochlearis $f$. cochlearis & Daphnia parvula & \\
Keratella cochlearis $f$. tecta & Diaphanosma brachyurum & \\
Ploeosoma sp. & & \\
Polyarthra sp. & & \\
Synchaeta sp. & & \\
Trichocerca sp. & & \\
\hline
\end{tabular}

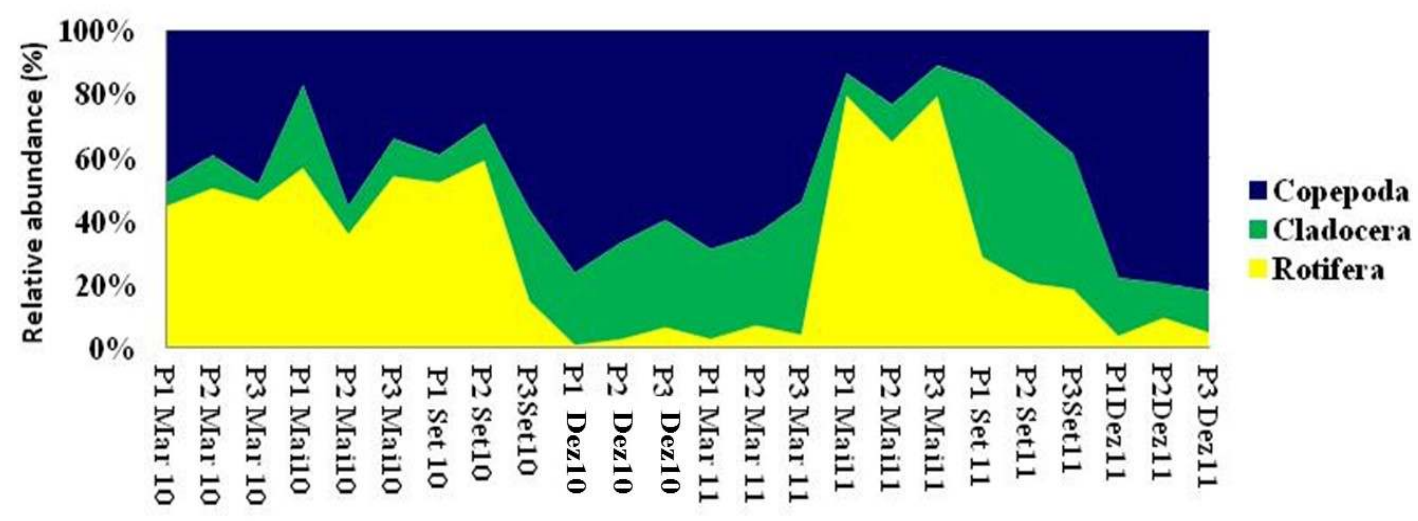

Fig. 3. Relative abundance (\%) of Rotifera, Copepoda and Cladocera in the sampling sites from March to December 2010 and 2011

\section{DISCUSSION}

During the period of study, zooplankton community followed a pattern strongly influenced by two gradients. The first was the temporal gradient that is related to temperature, and the other was the trophic gradient, related to algal biomass ( $\mathrm{CHL}$ a), which ultimately influenced Secchi disk depth (Figs. 4, 5, 6 and 7). A seasonal succession was apparent in this zooplankton community, with species dominating under changing suitable conditions respectively. In March and December (winter and early spring), Tropocyclops prasinus, Copidodiaptomus numidicus, Daphnia longispina and Bosmina coregoni were more abundant, and some of them became virtually absent in May and September (early and late summer), being replaced by Rotifera, Ceriodaphnia pulchella, Diaphanosma brachyurum and Chydorus sphaericus, which are more thermophylic and typical for more eutrophic environments [14,15]. This shift was also influenced by algal biomass and composition: In May and September, phytoplankton community was dominated by Cyanobacteria [16,17(authors' unpublished data)]. The conditions created by late spring and summer temperatures and irradiance combined with a plausible higher level of nutrients must have been provided the ecological optimum for Cyanobacterial dominance $[18,19]$. It is well known that either because of low nutritional value or by clogging the feeding apparatus or by producing toxins, Cyanobacteria may be important drivers in zooplankton composition and abundance [20-22]. In the presence of Cyanobacteria, zooplankton composition changed frequently, where large Cladocera (such as Daphnia longispina) and herbivorous Copepoda (such as Copidodiaptomus numidicus) are often replaced by Rotifera and other zooplankters specializing on small particle feeding, whose food preferences are mostly detritus-bacteria [2]. Similar results were observed in other reservoirs influenced by Mediterranean climate [23-26]. 


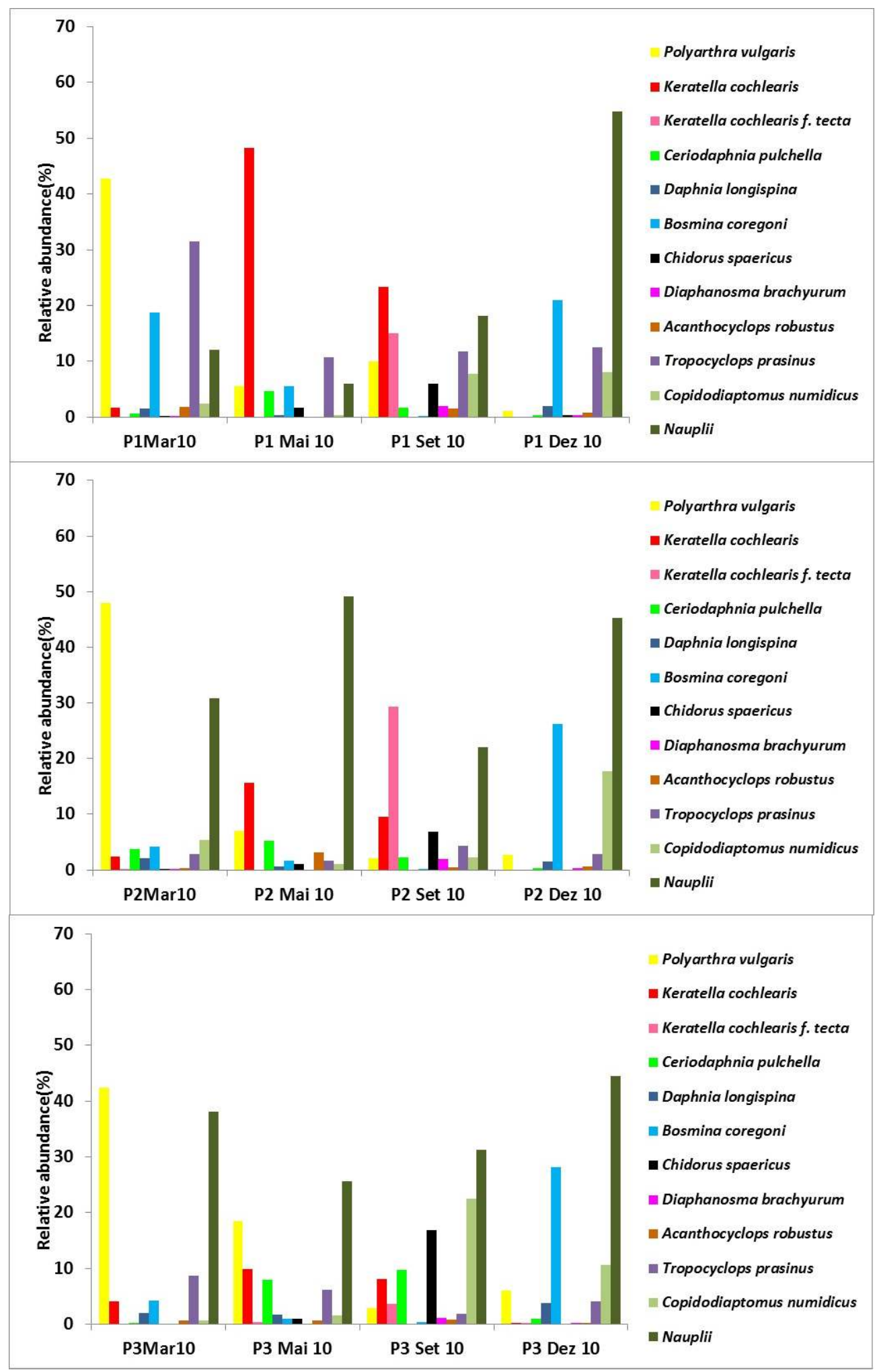

Fig. 4. Spatial-temporal variation of relative abundance and composition of the most abundant zooplankton taxa in March, May, September and December 2010 


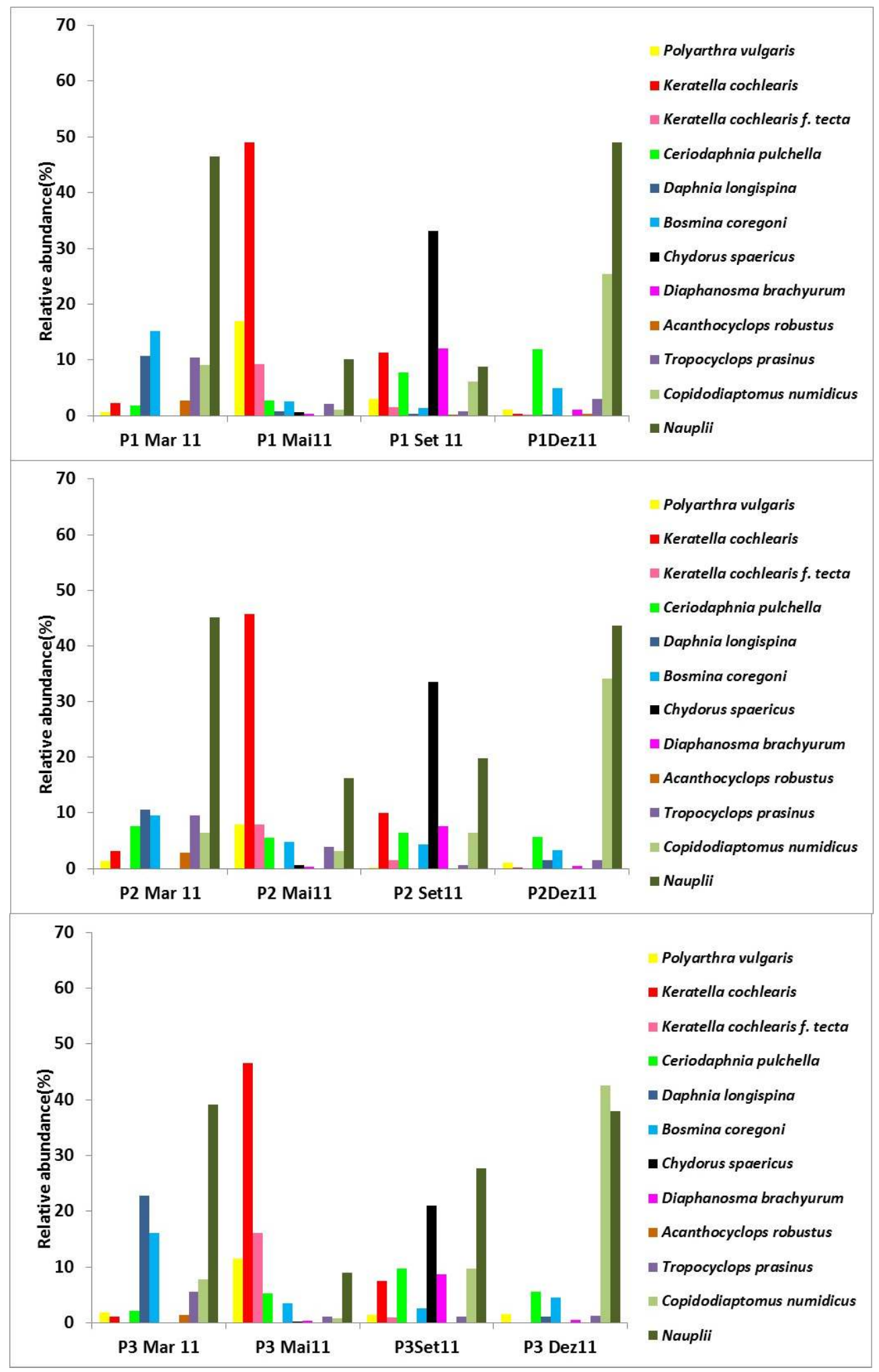

Fig. 5. Spatial-temporal variation of relative abundance and composition of the most abundant zooplankton taxa in March, May, September and December, 2011 


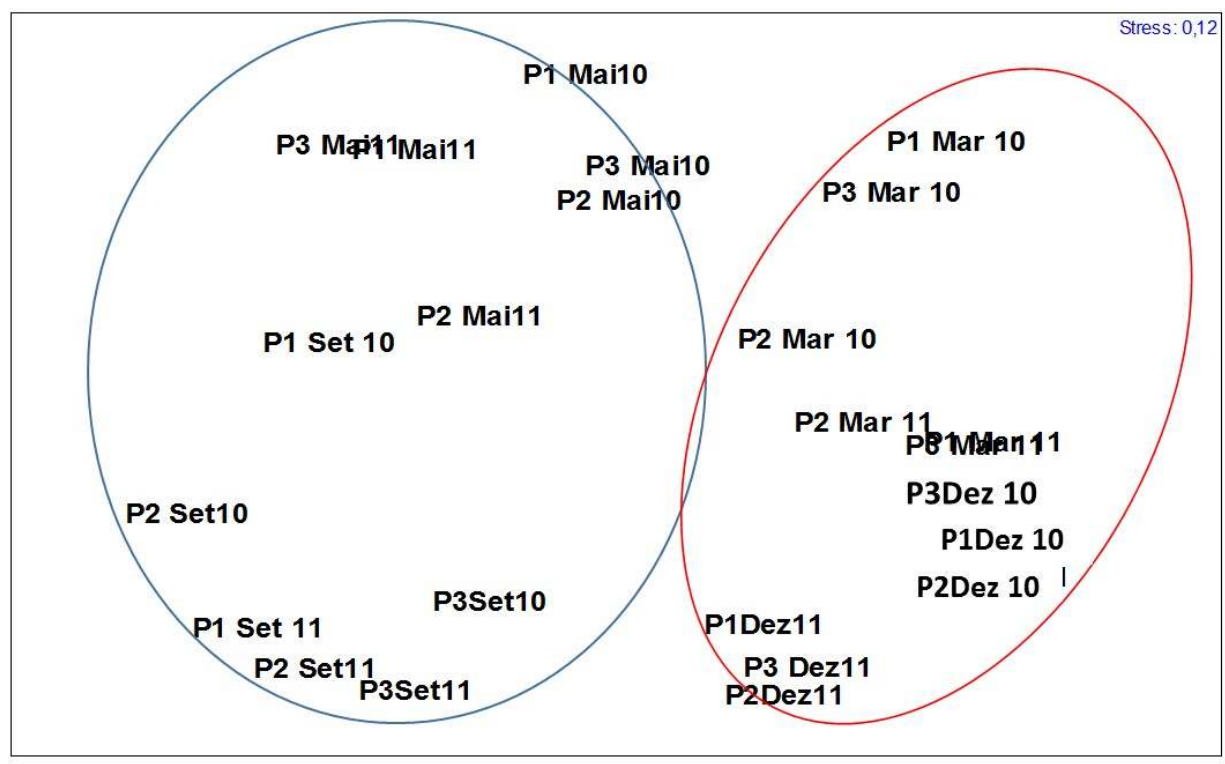

Fig. 6. Results of $\mathbf{n}$-MDS ordination considering zooplankton P1, P2, P3 - sampling sites.

Dez, Mar, Mai Set-Samples obtained in December, March, May and September, respectively

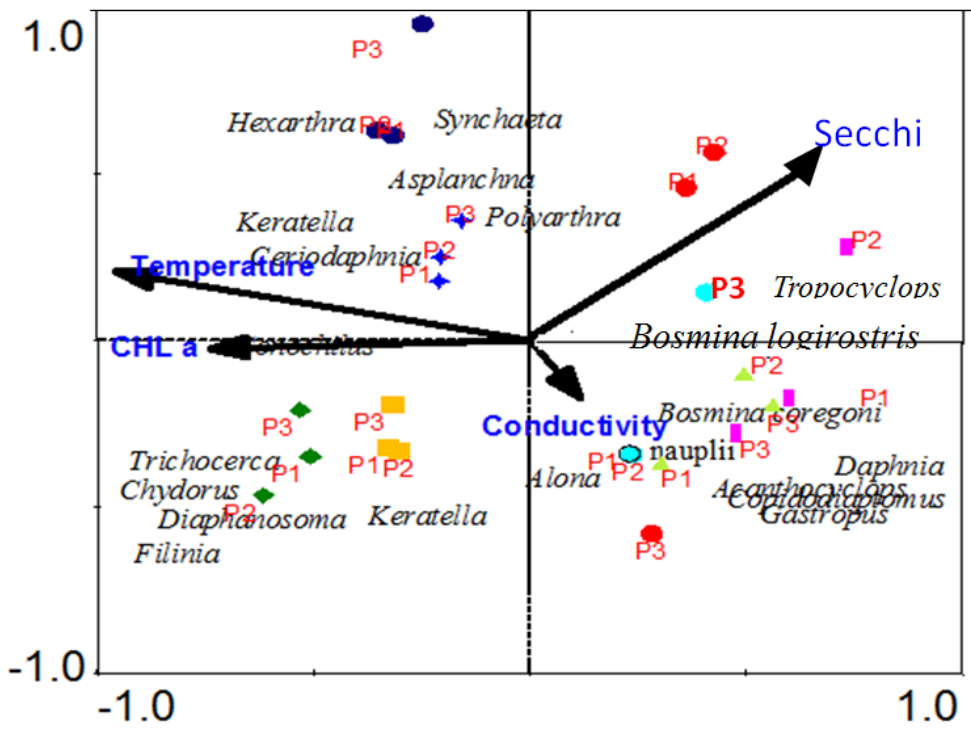

Fig. 7. Results of CCA

Scatters with samples: March 2010 - red circles; May 2010 - blue stars; September 2010 - yellow squares; December 2010 - pink rectangles; March2011 - green triangles; May 2011 - dark blue circles; September 2011 -green diamonds; December 2011- light blue circles

\section{CONCLUSION}

The preliminary results of the present study suggest that temperature had a direct and strong influence on the zooplankton community patterns. However, a wide range of physical, chemical and biotic interactions are likely to influence zooplankton abundance and community structure. Therefore, it is necessary to be cautious when relating the observed shifts exclusively with temperature and in the presence of Cyanobacteria. Some of the observed 
changes might be influenced by the other complex abiotic/biotic interactions independently of those studied in the present approach. Thus, further research will be required in order to understand the complexity of the interactions between biological, environmental and climatic parameters in this reservoir.

\section{ACKNOWLEDGEMENTS}

To the anonymous reviewers whose suggestions helped much to improve the present manuscript.

\section{COMPETING INTERESTS}

Authors have declared that no competing interests exist.

\section{REFERENCES}

1. Wetzel RG. Limnology - lake and river ecosystems. 3rd ed. New York: Academic Press; 2001.

2. Lampert W. Sommer U. Limnoecology the ecology of lakes and streams. New York: Oxford University Press; 1997.

3. Jeppesen $E$, Nõges $P$, Davidson TA, Haberman J, Nõges T, Blank $\mathrm{K}$, et al. Zooplankton as indicators in lakes: A scientific-based plea for including zooplankton in the ecological quality assessment of lakes according to the European water framework directive (WFD). Hydrobiologia. 2011;676:279-97.

4. Jeppesen E, Jensen JP, Sondergaard M, Lauridsen T. Trophic dynamics in turbid and clear water lakes with special emphasis on the role of zooplankton for water clarity. Hydrobiologia. 1999;408: 217-31.

5. Pereira R, Soares AMVMR, Ribeiro F, Gonçalves F. Assessing the trophic state of Linhos Lake: A first step towards ecological rehabilitation. Journal of Environmental Management. 2002;64: 285-97.

6. Abrantes N, Nogueira A, Gonçalves F. 2009 - Short-term dynamics of cladocerans in a eutrophic shallow lake during a shift in the phytoplankton dominance. Annales de Limnologie - International Journal of Limnology. 2009;45:237-45.

7. Obertegger U, Borsato A, Flaim G. Rotifercrustacean interactions in a pseudokarstic lake: Influence of hydrology. Aquatic Ecology. 2010;44:121-30.

8. Haberman J, Haldna M. Indices of zooplankton community as valuable tools in assessing the trophic state and water quality of eutrophic lakes: Long term study of Lake Võrtsjärv. J. Limnol. 2014;73(2): 263-73.

9. Anonymous. Plano de ordenamento da Albufeira da Aguieira. Direcção de serviços de utilizações do domínio hídrico divisão de ordenamento e protecção. Instituto da Agua; 2005. (Portuguese).

10. APHA. Standard methods for the examination of water and wastewater. 17th ed. Washington: American Public Health Association; 1989.

11. Carlson RE. A trophic state index for lakes. Limnol. Oceanogr. 1977;22:361 69.

12. Clarke KR, Warwick RM. Change in marine communities: An approach to statistical analysis and interpretation. Natural Environmental Research Council, UK; 1994.

13. Ter Braak CJF. Ordination. In: Jongman RHG, Ter Braak CJF, van Tongeren OFR, editors. Data analysis in community and landscape ecology. Cambrige: University Press; 1995.

14. Sladecȩek V. Rotifers as indicators of water quality. Hydrobiologia. 1983; 100:169-201.

15. Verbitskii VB, Verbitskaya TI, Malysheva OA. Population dynamics of Daphnia longispina (O.F. Müller, 1785) and Diaphanosoma brachyurum (Lievin, 1848) (Crustacea, Cladocera) under stable and graded temperature regimes. Biol. Bull. Russ. Acad. Sci. 2009;66-73.

16. Oliveira MRL, Monteiro MT. "Blooms" de cyanophyceae na Albufeira da Aguieira: Efeitos na qualidade da água e no zooplâncton. Relat. Téc. Cient. INIP. 1992; 61. (Portuguese).

17. Vasconcelos V. Toxic cyanobacteria In the Mondego basin reservoirs. An overview. In: Pardal MA, Marques JC, Graça MA, editors. Aquatic ecology of the Mondego River Basin: Global importance of local experience. Coimbra. Imprensa da Universidade de Coimbra; 2002.

18. Barone R, Castelli G, Naselli-Flores L. Red sky at night cyanobacteria delight: The role of climate in structuring phytoplankton assemblage in a shallow, Mediterranean lake (Biviere di Gela, southeastern Sicily). Hydrobiologia. 2010;639:43-53.

19. Huber V, Wagner C, Gerten D, Adrian R. To bloom or not to bloom: Contrasting responses of cyanobacteria to recent heat waves explained by critical thresholds of 
abiotic drivers. Oecologia. 2009;169(1): 245-56.

20. Geller W, Müller H. The Filtration Apparatus of cladocera: Filter mesh-sizes and their implications on food selectivity. Oecologia. 1981;49:316 -21.

21. Łotocka M. Toxic effect of cyanobacterial blooms on the grazing activity of Daphnia magna straus. Oceanologia. 2001;43:44153.

22. Sarnelle O, Gustafsson S, Hansson LA. Effects of cyanobacteria on fitness components of the herbivore Daphnia. Journal of Plankton Research. 2010:32(4): 471-77.

23. Geraldes AM, Boavida MJ. What factors affect the pelagic cladocerans of the mesoeutrophic Azibo reservoir? Annales de
Limnologie - International Journal of Limnology. 2004;40:101-11.

24. Geraldes AM, Boavida MJ. Zooplankton assemblages in two reservoirs: One subjected to accentuated water level fluctuations, the other with more stable water levels. Aquat Ecol. 2007;41:273-84.

25. Caramujo MJ, Boavida MJ. The crustacean communities of River Tagus reservoirs. Zooplankton structure as reservoir trophic state indicator. Limnética. 2000;18:37-56.

26. Castro BB, Antunes SC, Pereira R, Soares AMVM, Gonçalves F. Rotifer community structure in three shallow lakes: Seasonal fluctuations and explanatory factors. Hydrobiologia. 2005;543:221-32.

(c) 2016 Geraldes et al.; This is an Open Access article distributed under the terms of the Creative Commons Attribution License (http://creativecommons.org/licenses/by/4.0), which permits unrestricted use, distribution, and reproduction in any medium, provided the original work is properly cited.

Peer-review history:

The peer review history for this paper can be accessed here: http://sciencedomain.org/review-history/17547 